\title{
Sequencing and analysis of the divergon comprising gtaB, the structural gene of UDP-glucose pyrophosphorylase of Bacillus subtilis 168
}

\author{
Blazenka Soldo, $\dagger$ Vladimir Lazarevic, Philippe Margot $\ddagger^{\dagger}$ and Dimitri Karamata* \\ Institut de génétique et de biologie microbiennes, Rue César-Roux 19, CH-1005 Lausanne, Switzerland
}

(Received 6 April 1993; revised 25 June 1993; accepted 5 July 1993)

\begin{abstract}
Nucleotide sequencing revealed that gtaB, the structural gene of UDP-glucose pyrophosphorylase (EC 2.7.7.9), is part of a divergon-like genetic entity. The latter consists of two monocistronic operons gta $B$ and orf $X$, transcribed from a 245 bp regulatory region, each encoding an acidic protein with a molecular mass of 33.0 and $42.6 \mathrm{kDa}$, respectively. gtaB is transcribed from a distal $\mathrm{P}^{A}$ promoter, and a proximal $\mathrm{P}^{B}$ promoter which is negatively controlled by the Sin protein. Sin-mediated transcriptional attenuation and enhancement of $P^{B}$ and $P^{D}$, respectively, suggest that these promoters control functions which antagonize each other. Transcription of orf $X$ is mediated by a $P^{A}$ promoter. The regulatory region comprises four ATGAAA hexamers, present as two inverse repeats. Protein GtaB exhibits high homology to analogous prokaryotic enzymes, while OrfX shows 55.4\% homology with the product of Escherichia coli o389, which is part of a regulatory unit involved in sugar processing. Mutations gtaB515 and $\operatorname{gtaB}^{g} 100$, which define different bacteriophage adsorption patterns, were sequenced. They are transitions leading to substitution of amino acids which occupy conserved positions, and are thus likely to be part of an enzyme active site. The nature of the possible receptors for defective bacteriophages PBSY and PBSZ is discussed.
\end{abstract}

\section{Introduction}

UDP-glucose pyrophosphorylase (UDPGPPase) catalyses the synthesis of UDP-glucose (UDPG) from glucose 1-phosphate and UTP. UDPG participates in a variety of enzymic reactions which include: (i) metabolism of polysaccharides (glycogen, starch, laminarin and cellu-

\footnotetext{
*Author for correspondence. Tel. $+41213206075 ;$ fax +4121320
} 6078 .

$\dagger$ Permanent address: Centar za geneticko inzenjerstvo i biotehnologiju, Filipa Kljajica 12, 71000 Sarajevo, Bosnia and Herzegovina.

$\ddagger$ Present address: Department of Molecular and Experimental Medicine, Division of Cellular Biology, The Scripps Research Institute, 10666 North Torrey Pines Road, La Jolla, CA 92037, USA.

Abbreviations: GalNAc, $N$-acetylgalactosamine; $\mathrm{Cm}^{\mathrm{r}}$, chloramphenicol-resistant; $\mathrm{Em}^{r}$, erythromycin resistant; phage $^{r / s}$, phage resistance/sensitivity; poly(Glc-GalNAc 1-P), poly(3- $O-\beta$-D-glucopyranosyl- $N$-acetylgalactosamine 1-phosphate); poly(groP), poly(glycerol phosphate); RBS, ribosome-binding site; UDPG, UDP-glucose; UDPGPPase, UDP-glucose pyrophosphorylase.

The GenBank and EMBL accession number for the sequence reported in this paper is Z22516. lose), disaccharides (sucrose, trehalose), $\beta$-glucosides, UDP-glucuronate and glucosyl-ceramide (Hassid, 1969; White et al., 1973); (ii) galactose entry into glycolysis; (iii) synthesis of periplasmic membrane-derived oligosaccharides (Miller et al., 1986) which could play a role in osmotic adaptation of Gram-negative bacteria (Schulman \& Kennedy, 1977); (iv) glucosylation of hydroxymethylcytosine residues in cells infected by $\mathrm{T}$ even bacteriophages (Shedlovsky \& Brenner, 1963); and (v) synthesis of the core region of lipopolysaccharides in Gram-negative bacteria (Sundararajan et al., 1962). In the Gram-positive bacterium Bacillus subtilis, strain 168, UDPG is required for the glucosylation of the poly(glycerol phosphate) [poly(groP)] (Young, 1967), the major cell wall teichoic acid (Baddiley, 1970), and for the polymerization of the secondary anionic polymer, the poly(3-O- $\beta$-D-glucopyranosyl- $N$-acetylgalactosamine 1 phosphate [poly(Glc-GalNAc 1-P)] (Shibaev et al., 1973).

The $B$. subtilis 168 gene gtaB, which encodes UDPGPPase, has been mapped in the his $A$ region (Young et al., 1969; Pooley et al., 1987), and subsequently physically localized close to the tag genes (Mauël et al., 1989). The UDPGPPase activity in extracts of nine strains, each bearing a different gtaB mutation, was found to be below $2 \%$ of that of the wild-type. All 
mutations were associated with resistance to bacteriophage $\phi 29$ (Pooley, 1987). Study of phage sensitivity spectra has, however, revealed the existence of two classes of mutants. Those carrying a gtaB mutation were resistant to defective bacteriophages PBSY and PBSZ, while those endowed with the so-called gta $B^{g}$ mutation were, like the wild-type strain, sensitive to these phages. Although in both classes the content of cell-wallassociated galactosamine was significantly reduced, it was five times higher in strains with $g t a B^{g}$ mutations than in those bearing $g t a B$ ones.

To understand the regulation of UDPGPPase synthesis, as well as the difference between the abovementioned phenotypes, we have sequenced the gtaB regulatory unit, and the mutant alleles gtaB515 and gtaB $B^{g} 100$. We report the complete nucleotide sequence of the gtaB-containing divergon, which consists of two divergently transcribed monocistronic operons.

\section{Methods}

Bacterial strains, plasmids and phages. These are listed in Table 1. Fragments from the $B$. subtilis chromosomal DNA insert in phage $\lambda 63$ (Mauël et al., 1989) were subcloned in pMTL20EC (Chambers et al., 1988), except for the insert in plasmid 6301, which was cloned in pJH101 (Ferrari et al., 1983) and maintained in Escherichia coli strain DH5.

Media and growth. E. coli strains were grown in LB medium containing the following selective agents: ampicillin $\left(50 \mu \mathrm{g} \mathrm{m}^{-1}\right)$, erythromycin $\left(10 \mu \mathrm{g} \mathrm{m}^{-1}\right)$, and chloramphenicol $\left(10 \mu \mathrm{g} \mathrm{ml}^{-1}\right)$. B. subtilis strains were grown in SPIZ I, SPIZ II, SA and LB media as previously described (Karamata \& Gross, 1970). When required, media were supplemented with amino acids $\left(20 \mu \mathrm{g} \mathrm{ml}^{-1}\right)$, adenine $\left(100 \mu \mathrm{g} \mathrm{ml}^{-1}\right)$, chloramphenicol $\left(3 \mu \mathrm{g} \mathrm{ml}^{-1}\right)$ or both erythromycin $\left(1 \mu \mathrm{g} \mathrm{ml}^{-1}\right)$ and lincomycin $\left(25 \mu \mathrm{g} \mathrm{m}^{-1}\right)$.

DNA preparation. B. subtilis chromosomal DNA was isolated by the method of Marmur (1961). Plasmid DNA was prepared by the boiling method miniprep (Del Sal et al., 1988). DNA fragments, separated by electrophoresis on $0.8 \%$ agarose gels, were extracted from gel slices and purified by centrifugation through siliconized sterile glass wool (Heery et al., 1990).

Transformation. Competent cells of $E$. coli DH5 were prepared and transformed by the procedure of Chung \& Miller (1988). Transformation of $B$. subtilis was performed as described by Karamata \& Gross (1970). Chloramphenicol-resistant $\left(\mathrm{Cm}^{r}\right)$ transformants were selected on LB plates supplemented with chloramphenicol $\left(3 \mu \mathrm{g} \mathrm{ml}^{-1}\right)$. Before plating on LA plates containing erythromycin and lincomycin, the transformation mixture was incubated for an additional $90 \mathrm{~min}$ period with a sublethal concentration of erythromycin $\left(0.1 \mu \mathrm{g} \mathrm{ml}^{-1}\right)$.

Determination of phage susceptibility. Phage $\phi 29$ was propagated on strain BD70. Stocks of the defective bacteriophages PBSY and PBSZ were obtained by mitomycin $C$ induction of cultures of $B$. subtilis strains S31 and W23, respectively, and prepared as previously described (Mauël \& Karamata, 1984; Karamata et al., 1987). Phage susceptibility was assessed by spotting the stocks onto fresh streaks of purified $\mathrm{Cm}^{\mathrm{r}}$ transformants, and incubating at $37^{\circ} \mathrm{C}$ for $6 \mathrm{~h}$.

Polymerase chain reaction $(P C R)$. PCRs were performed on DNA substrates, purified by $\mathrm{CsCl}$ /ethidium bromide gradient centrifugation
(Sambrook et al., 1989) with the GeneAmp PCR reagent kit (Perkin Elmer Cetus). After an initial 1 min denaturation step at $95^{\circ} \mathrm{C}$, the amplification was carried out for 30 rounds: 1 min denaturation at $95^{\circ} \mathrm{C}$ alternating with $1 \mathrm{~min}$ annealing at $37^{\circ} \mathrm{C}$ and 1 min extension at $72^{\circ} \mathrm{C}$. The polymerization was completed by a $3 \mathrm{~min}$ incubation at $72{ }^{\circ} \mathrm{C}$. Samples were extracted with chloroform, digested with the appropriate restriction enzymes and cloned in pMTL20EC.

DNA sequencing and analysis. DNA fragments cloned into pMTL20EC were deleted using the double-stranded nested deletion kit (Pharmacia), and sequenced with the Sequenase version 2.0 kit (US Biochemical). The $\left.{ }^{35} S\right] d A T P \alpha S$ was from Amersham. Sequence data were compiled and analysed with the University of Wisconsin Computer Group software (Devereux et al., 1984).

Isolation of total RNA and primer extension. Cultures grown in SA medium at $37^{\circ} \mathrm{C}$ were harvested at a concentration of $2 \times 10^{8}$ cells ml ${ }^{-1}$, and total RNA was isolated according to the method of Gilman \& Chamberlin (1983). Relevant oligodeoxynucleotides, identified from the sequence analysis, i.e. 5'AAGAAAACGTGTTCCTAAGCCTG3' for $g t a B$ and 5'TCTTGATCGCTTCAGGCCTGGTC $3^{\prime}$ for orf $X$, both situated between nucleotides 17 and 40 downstream of their respective start codons, were synthesized with a Beckman SM oligonucleotide synthesizer and purified on a NAP-25 (Pharmacia) column. Twenty picomoles was radiolabelled in a $50 \mu \mathrm{l}$ mixture containing 20 units of T4 polynucleotide kinase (Biofinex) and $100 \mu \mathrm{Ci}(3.7 \mathrm{MBq})$ of $\left[\gamma^{-}{ }^{32} \mathrm{P}\right] \mathrm{ATP}\left(>5000 \mathrm{Ci} \mathrm{mmol}^{-1}\right.$, Amersham), and purified by ethanol precipitation (Sambrook et al., 1989). Primer extensions were performed with $1.5 \mathrm{pmol}$ of these probes and $50 \mu \mathrm{g}$ of total cellular RNA (Jones et al., 1985). The extension products were resuspended in $6 \mu \mathrm{l}$ $50 \%(\mathrm{v} / \mathrm{v})$ formamide, and loaded onto polyacrylamide gels, together with sequencing reaction products.

Amylase detection. $\mathrm{Cm}^{\mathrm{r}}$ transformants of strain L5047 were tested for the inactivation of the amylase gene as follows. After $18 \mathrm{~h}$ incubation on chloramphenicol and $1 \%(\mathrm{w} / \mathrm{v})$ starch-supplemented LA plates. colonies were flooded with $0.5 \%(\mathrm{w} / \mathrm{v})$ iodine in $1 \%(\mathrm{w} / \mathrm{v})$ potassium iodide. Amylase deficiency, due to amyE locus disruption, was revealed by absence of clearing around colonies.

\section{Results}

\section{The nucleotide sequence of the gtaBorf $X$ divergon}

Transformation of a gtaB-bearing strain with p6312 (Fig. 1) yielded recombinants with the wild-type phage susceptibility spectrum (C. Mauël, unpublished results). Thus, the relevant $2.5 \mathrm{~kb}$ region, comprising the insert of p6312 (Fig. 1), was sequenced on both strands by the dideoxy chain-termination method. Computer analysis of the sequence revealed two open reading frames (Figs 1 and 2): $\operatorname{orf} X$, transcribed in the direction of DNA replication, and $g t a B$, the structural gene of the UDPGPPase, transcribed in the opposite direction. Potential AUG translation initiation codons for gtaB and $\operatorname{orf} X$ are separated by an intergenic regulatory region of $245 \mathrm{bp}$, and preceded by Shine-Dalgarno sequences with $\Delta G \mathrm{~s}$ of -11.9 and $-12.4 \mathrm{kcal} \mathrm{mol}^{-1}$ $\left(-49.8\right.$ and $\left.-51.9 \mathrm{~kJ} \mathrm{~mol}^{-1}\right)$ respectively. The UAA stop codons of both ORFs are followed by inverted repeats, which could generate stem-loop structures with a $\Delta G$ of 
Table 1. Bacterial strains, plasmids and bacteriophage

\begin{tabular}{|c|c|c|}
\hline Name & Genotype or description & Origin \\
\hline \multicolumn{3}{|l|}{ Bacillus subtilis } \\
\hline L5047 & pheA1 purA16 hisA35 trpC2 metB5 & Mauël et al. (1989) \\
\hline L6200 & his Al argC4 ilvAl gta $B^{g} 100$ & Pooley et al. (1987) \\
\hline L5054 & pheA1 purA16 hisA35 trpC2 gtaB515 & Pooley et al. (1987) \\
\hline L6331 & purAI6 leuA8 ilvAl gtaB515 & Pooley \& Karamata (1984) \\
\hline L4598 & pheA1 purA16, his 335 trpC 2 metB5 gtaB:: 66344 & Integration of p6344 into the $\mathrm{gtaB}$ locus of L5047 \\
\hline L4599 & $\begin{array}{l}\text { phe A1 purA16 hisA35 trpC2 metB5 amyE::cat } \\
\text { orf } X \Delta \text { lac } Z\end{array}$ & $\begin{array}{l}\text { Insertion of fragment containing cat, } 0.6 \mathrm{~kb} \text { fragment of } \\
\operatorname{orf} X \text { and } \operatorname{lac} Z \text {, into the amyE locus of } \mathrm{L} 5047\end{array}$ \\
\hline L4600 & $\begin{array}{l}\text { phe Al purAl6 his } A 35 \text { trpC } 2 \text { metB5 amyE::cat } \\
\left.\text { orf } X \Delta(:: \mathrm{p} 6350) \text { lac } Z \text { (orf } X^{+}\right)\end{array}$ & $\begin{array}{l}\text { Integration of p } 6350 \text { into the partial copy of orf } X \text { of } \\
\text { L4599 }\end{array}$ \\
\hline S 31 & Prototroph & Ionesco et al. (1964) \\
\hline W23 & Prototroph $\mathrm{Sm}^{\mathrm{r}}$ & Dubnau et al. (1967) \\
\hline BD70 & $\operatorname{met} C 3 \operatorname{trp} C 2$ & Dubnau et al. (1967) \\
\hline IS432 & leuA8 metB5 hisAl $\sin \Delta \mathrm{Cm}^{\mathrm{r}}$ & $\begin{array}{l}\text { I. Smith, Public Health Research Institute, New York, } \\
\text { USA }\end{array}$ \\
\hline \multicolumn{3}{|l|}{ Escherichia coli } \\
\hline DH5 & 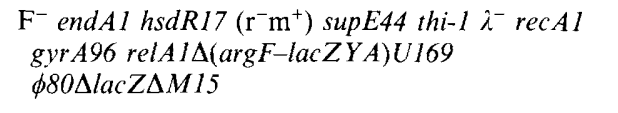 & P. Shaw, Université de Lausanne \\
\hline \multicolumn{3}{|l|}{ Phage } \\
\hline$\lambda 63$ & $\begin{array}{l}\text { Contains a } 17.3 \mathrm{~kb} \text { fragment of B. subtilis } 168 \\
\text { chromosomal DNA }\end{array}$ & Mauël et al. (1989) \\
\hline \multicolumn{3}{|l|}{ Plasmids } \\
\hline pMTL20EC & $\mathrm{Ap}^{\mathrm{r}} \mathrm{Em}^{\mathrm{r}} \mathrm{Cm}^{\mathrm{r}}$ & Chambers et al. (1988) \\
\hline pMTL500C & $\mathrm{Ap}^{\mathrm{r}} \mathrm{Cm}^{\mathrm{r}}$ oripAM $\beta 1$ & N. P. Minton, Porton, UK \\
\hline pJHIOI & $A p^{r} T^{r} C^{r}$ & Ferrari et al. (1983) \\
\hline pDG268 & $\mathrm{Ap}^{\mathrm{r}} \mathrm{Cm}^{\mathrm{r}}$ amyE: : cat lac $Z$ & P. Stragier, Université Paris-Sud, France \\
\hline pVL22 & $A p^{r} \mathrm{Em}^{r} \mathrm{Cm}^{r}$ & HindIII-BgIII deletion in the polylinker of pMTL20EC \\
\hline p6344 & $\mathrm{Ap}^{\mathrm{r}} \mathrm{Em}^{\mathrm{r}} \mathrm{Cm}^{\mathrm{r}}$ & $\begin{array}{l}\text { Cloning of the } 0.6 \mathrm{~kb} \mathrm{DraI}-\mathrm{Bg} / \mathrm{II} \text { fragment from p } 6312 \\
\text { into the SmaI and } B g l \mathrm{Il} \text { sites of pMTL20EC }\end{array}$ \\
\hline p6344A & $\mathrm{Ap}^{\mathrm{T}} \mathrm{Cm}^{\mathrm{r}}$ oripAM $\beta 1$ & 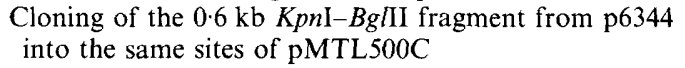 \\
\hline p6346 & $\mathrm{Ap}^{\mathrm{r}} \mathrm{Em}^{\mathrm{r}} \mathrm{Cm}^{\mathrm{r}}$ & $\begin{array}{l}\text { The } 0.6 \mathrm{~kb} \mathrm{HpaI-SacI} \text { insert of p } 6320 \text { cloned into } \\
\text { SmaI-Sacl sites of pMTL20EC. }\end{array}$ \\
\hline p6347 & $\mathrm{Ap}^{r} \mathrm{Em}^{r} \mathrm{Cm}^{r}$ & $\begin{array}{l}\text { The } 0.75 \mathrm{~kb} \text { HindIII-Bg/II chromosomal fragment of } \\
\text { L5054 cloned into the same sites of pMTL20EC }\end{array}$ \\
\hline p6348 & $\mathrm{Ap}^{r} \mathrm{Em}^{\mathrm{r}} \mathrm{Cm}^{\mathrm{r}}$ & $\begin{array}{l}\text { The } 0.75 \mathrm{~kb} \text { HindIII- } B g / \mathrm{II} \text { chromosomal fragment of } \\
\text { L6200 cloned into the same sites of pMTL20EC }\end{array}$ \\
\hline p6349 & $\mathrm{Ap}^{\mathrm{r}} \mathrm{Cm}^{\mathrm{r}}$ amyE::cat lac $Z$ & $\begin{array}{l}\text { Cloning of the } 0.6 \mathrm{~kb} \text { Bam HI-EcoRI fragment from } \\
\text { p6346 into the same sites of pMTL20EC }\end{array}$ \\
\hline p6350 & $A p^{r} E^{r}$ & $\begin{array}{l}\text { Cloning of the } 0.6 \mathrm{~kb} E c o \mathrm{RI}-H p a \mathrm{I} \text { insert from } \mathrm{p} 6320 \\
\text { into the EcoRI-StuI of pVL22 }\end{array}$ \\
\hline
\end{tabular}

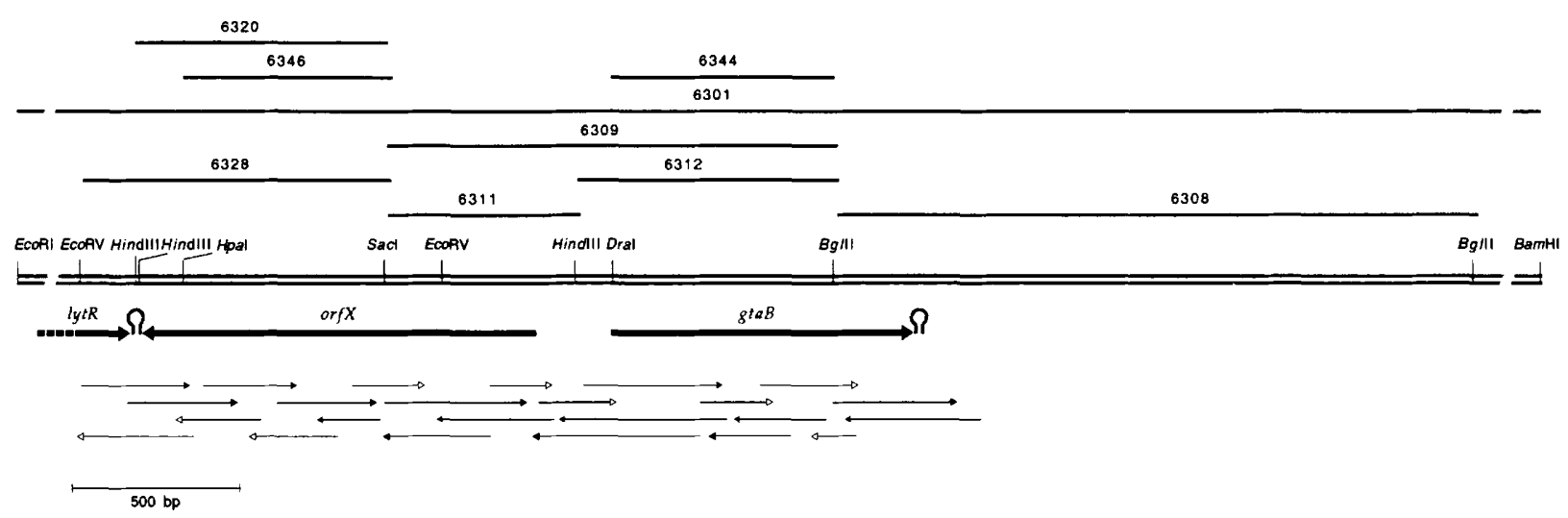

Fig. 1. Sequencing strategy. The sequence was determined on both strands using sets of nested deleted inserts derived from plasmid subclones (-). Thin arrows indicate the direction and the length of each independently determined sequence using M13 $(\longrightarrow$ ) or synthesized primers $(\longrightarrow)$. ORFs are indicated under the restriction map $(\rightarrow)$. DNA replication proceeds from right to left. 
(ECORV)

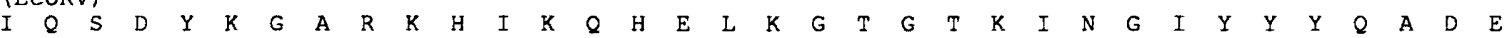
atccagtccgat tacaaggtgcgcggaa acatattaaacagcacgaact aaaggtacaggcacgaaatcaatggaatttactactaccaagctgatg

$\begin{array}{llllllllllllllllllll}S & A & L & S & D & I & T & K & E & L & K & E & S & L & E & K & * & H i n d I I I\end{array}$

aagcgcccttccgatattacaaagagctgaaggaagcctcgaaagtaaacaaaagaagcttcgcacaatgtgcaaagct.cttttta 200 atttgttttcttcgaagcgtgttacacgtttcgaagaaaaataacg

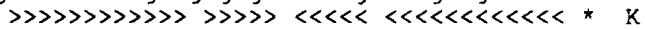

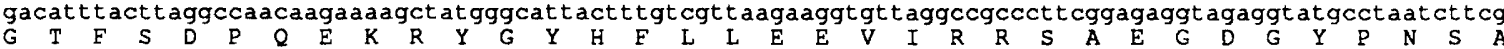

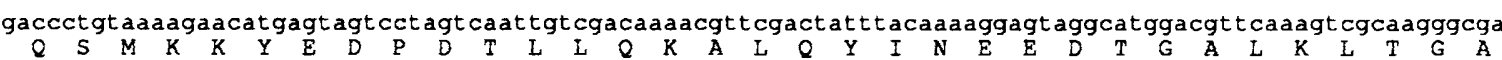

ggtgaggaagtccggcaaggcagcatagtgcgtcttgttcttggccaaagggetctctaccecgaaggaggacgtgcggcgggcttagccagttatatt E V G E P R E T T D R L V L V P K G L S P A E E Q V V G G S D T L I ttacgctaaagcgacgtttcaatacctttagctagtggagatttccaagttagtctacgtgagacagtcttagtggttttacgaatactcggcgaagggc 600 F H S K A A F N H F ctgttgtcctaagtccacgtgtcccatttgctgaacatgtagaagtttaaggggatgttaagacgcctaccggaatttgtacaaaaggtaaccgagtggg

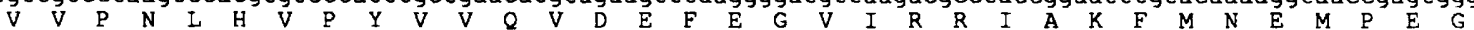
tttaaagggccgccactcgccagttctcttagtaaataggagtgggtggactagctcttgtcctacactcattggtagggattggcaacacaactcac 800 L N E R R H A T L L I M K D E G V Q D L V P H S Y G D R V T T N L

gcagttagcgacataacgggcaatgtttttatctcagccggaaaaacaaagaaaattatttaacagaaagcggaccggacagcctcgttttacgtt ag $\begin{array}{llllllllllllllllllllllllllllllllllllll}A & D & I & A & T & N & G & T & V & F & I & S & D & A & K & K & N & E & K & L & I & N & D & K & A & Q & G & T & P & A & F & H & L & D\end{array}$ SacI

tcgttagcggggacagtagacagctaactcgagaaggcctttgcccettatgaataagggacatgcetcggggcggaggtgtactggctgtcgttaaact 1000

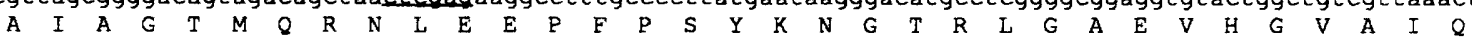

accattttcogccgatccgaaggccgtttgcagcagcagcatagtggtacctgttcgtgttatagcccaaactatagaaatt

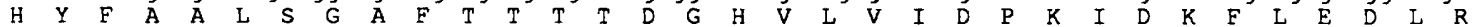

gttcacgcaatctgcattagagacggtcacagacggcgaggaagtattacaagtttagcttcagtccgaactacactttgcgtagattgtggactagctc 1200

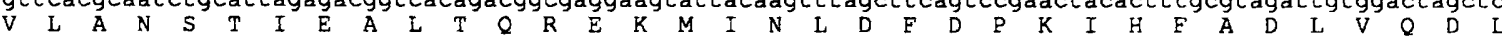

gtagacagacacgacacgtcaatggcaatgtatccttagataaagtcctataaaaagttaagttcgtgttcgccacggtagaactagcgaagtccggac 1300 $\begin{array}{lllllllllllllllllllllllllllllllll}M & Q & R & H & Q & A & T & V & T & V & Y & S & D & I & E & P & Y & K & K & L & E & L & V & L & P & A & M & K & I & A & E & P & R\end{array}$

attgtcacctggtttctgctatagtaataattcatactacatattctacatgaaatgcat 1400 cagggctttgccagtagtgaaatcaaaaghtataacagtggaccaaagacgat atcatt att aagt Atgatgtataagatgtact teacgta

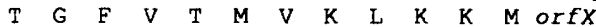

$$
-35 \mathrm{P}^{\mathrm{A}}-10 \mathrm{P}^{\mathrm{A}}-10 \mathrm{P}^{\mathrm{A}}
$$

cattt aaatcattcattcttgattcaaataaatgatataagtttaatattaaggataagcttatttaaaatggtttatccgatatcataaaat 1500

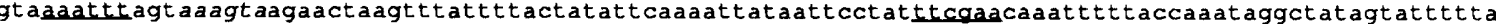
$-35 \mathrm{P}^{\mathrm{A}} \quad$ HindIII

$-35 \mathrm{P}^{\mathrm{B}}-10 \mathrm{P}^{\mathrm{B}} \quad \mathrm{RBS} \quad \mathrm{gtaB} \quad \mathrm{M} K \mathrm{~K} \quad \mathrm{~V} \quad \mathrm{~K} \quad \mathrm{~A}$ GtotaaaacatattgaaaggotaaatagagaatAgtt taaccataaatttttcgatcataaggaaggtgcgttttaaatgaaaaagtacgtaaagc 1600 cacattttgtataactttcccattatctct atcaaattggtatt aaaaagctagtattccttccacgcaaatt

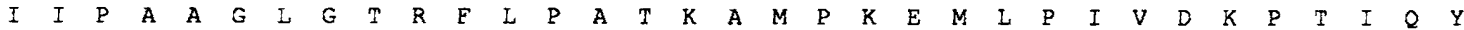
cataattccagcagcaggcttaggaacacgttttcttccggctacgaaagcaatgccgaaagaaatgcttcctatcgttgataaacctaccattcaatac 1700

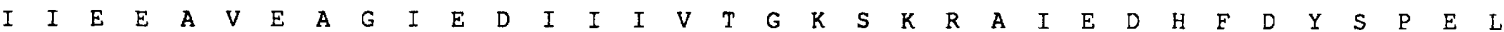
ataattgaagaagctgttgaagccggtattgaagatattattatcgtaacaggaaaaagcaagcgtgcgattgaggatcattttgattactctcctgagc 1800

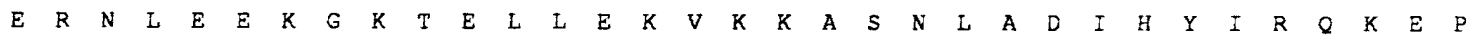
ttgaagaaacctagaagaaaaggaaaactgagctgcttgaaaagtgaaaaggcttctaacctggctgacattcactatatccgccaaaagaacc 1900

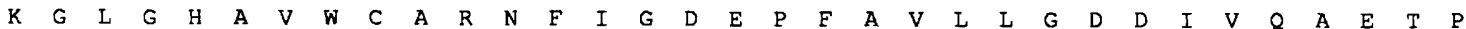
taaaggtctcggacatgctgtctggtgcgcacgcaactttateggcgatgagcegtttgcggtactgcttggtgacgatattgttcaggctgaaactcca 2000

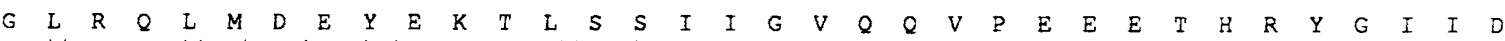
gggttgcgccaattaatggatgaatatgaaaaacactttct tctattatcggtgttcagcaggtgcccgaagaagaaacacaccgctacggcattattg 2100

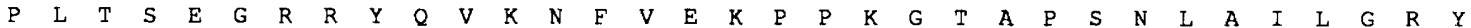
acccgctgacaagtgaaggcegccgttatcaggtgaaaacttcgttgaaaaccgcetaaaggcacagcaccttctaatcttgccatcttaggccgtta 2200

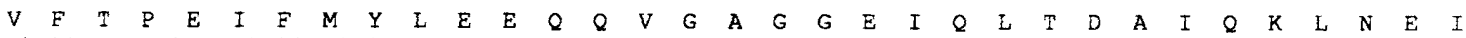
cgtattcacgcctgagatct catgtatttagaagagcagcaggttggcgecggeggagaattcagctcacagacgccattcaaaagctgaatgaaatt 2300 Bgl I I

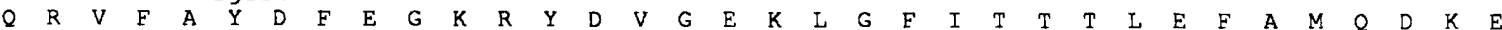

caagagtgtttgcttacgattttgaaggcaagcgttatgatgttggtgaaaagctcggctttatcacaacaactcttgaatttgcgatgcaggataaag 2400

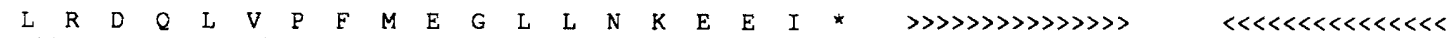
agcttcgcgatcagctcgttccatttatggaaggtttactaaacaagaagaaatctaaacaaaaggctattggacattcatccaatagcctttttta 2500 att gttttccgataacctgtaagtaggttatcggaaaaaat

Fig. 2. Nucleotide sequence of the $2.5 \mathrm{~kb}$ region containing $g t a B$ and orf $X$, and their deduced amino acid sequences. Major restriction sites are indicated. -35 and -10 promoter regions are underlined. Putative ribosome-binding sites (RBS) are doubly underlined. Uppercase letters in the nucleotide sequence indicate transcription start points. Asterisks denote stop codons. Regions of dyad symmetry are shown by converging arrowheads. Hexamer ATGAAA repeats are in italic. 
$-22.8 \mathrm{kcal} \mathrm{mol}^{-1} \quad\left(-95.4 \mathrm{~kJ} \mathrm{~mol}^{-1}\right)$ for $g \mathrm{taB}$ and $-24.9 \mathrm{kcal} \mathrm{mol}^{-1}\left(-104.2 \mathrm{~kJ} \mathrm{~mol}^{-1}\right)$ for $\operatorname{orf} X$, and function as $\rho$-independent transcriptional terminators. The inverted repeat downstream of orf $X$ acts as the terminator for the convergently transcribed $l y t R$ gene (Lazarevic et al., 1992).

\section{Deduced products of the gtaB and orf $X$ genes}

gtaB encodes an apparently cytoplasmic $33 \mathrm{kDa}$ protein, consisting of 292 amino acid residues, and having a $\mathrm{pI}$ of 4.94 (Table 2). Screening of the GenBank database revealed $42 \cdot 1 \%, 45.4 \%$ and $42 \cdot 4 \%$ homologies between the GtaB protein and UDPGPPases of Acetobacter xylinum (Brede et al., 1991), E. coli (A. C. Weissborn et al., unpublished results) and Salmonella typhimurium (Jiang et al., 1991), respectively (Fig. 3). The putative product of gene $\operatorname{orf} X$, containing 380 residues, has a molecular mass of $42.6 \mathrm{kDa}$ and a $\mathrm{pI}$ of $5 \cdot 76$. It exhibits $55.4 \%$ amino acid identity with an $E$. coli protein (Fig. 4) that is possibly involved in sugar processing (Daniels et al., 1992).
Table 2. Properties of the nucleotide sequence of the gtaB and orf $X$ genes and their deduced products

\begin{tabular}{lcc}
\hline \multicolumn{1}{c}{ Property } & gtaB & orf $X$ \\
\hline Start codon & AUG & AUG \\
Stop codon & UAA & UAA \\
Size of ORF (bp) & 876 & 1140 \\
TA in wobble position (\%) & 63 & $53 \cdot 6$ \\
TA (\%) & $56 \cdot 8$ & $53 \cdot 5$ \\
$\Delta G$ for RBS (kcal mol $\left.{ }^{-1}\right)^{*}$ & $-11 \cdot 9$ & $-12 \cdot 4$ \\
Length (amino acids) & 292 & 380 \\
Molecular mass (kDa) & $33 \cdot 0$ & $42 \cdot 6$ \\
Isoelectric point & $4 \cdot 9$ & $5 \cdot 7$ \\
Net charge & -11 & -14 \\
\hline \hline
\end{tabular}

* Calculated according to the rules of Tinoco et al. (1973) $(1 \mathrm{kcal}=$ $4 \cdot 184 \mathrm{~kJ})$.

\section{Transcription analysis of the gtaB and orf $X$ genes}

UDPG, whose synthesis is mediated by GtaB, is involved in the glucosylation of poly (groP) and in the synthesis of the main chain of poly(Glc-GalNAc 1-P) (Shibaev et al., 1973). Although neither of these roles is essential for the growth of $B$. subtilis 168 , the analysis of the gtaB and,
B. subtilis

A. xylinum

E. coli

s. typhimurium

B. subtilis

A. xylinum

E. coli

s. typhimurium

B. subtilis

A. xylinum

E. coli

S. typhimurium

\begin{abstract}
MKKVRRA I I PAAGLGT RF LPATKAMPKWLP IVDKP T IQY I IERAVEAGIED I I IVTGKSKRA I EDHFDYSPELERNLEEKGKTELLEKVKKASNL 96 MIKP LKKAVLPVAGLGTRF IPATKCVR KEUL TVVDRP L IOYA IDEAREAGIEEFCLVS SRGKD SL IDYFD ISYELEDTLKARKKT SALKALEATRVI 97 MAA INTKVKXAVI PVAGLGTRMIPATKA IPKTMLP LVDKP L IOYVVNEC IAAGI TE IVLVTHSSRNS IENHFDT SFELEAMLEKRVKRQLLDEVQS ICPP 100 MMNLRAVI PVAGLGMHMLPATRA IP KEWLP IVDKPMIQY I VDE IVAAGIKE IVLVT HASKNAVENHFDT S YELES LLEORVRROLLAEVQS ICPP 95
\end{abstract}

-AD IHY IRQKEP KGLGHAVWCARNF IGDEP EAVLLGDD IVQAE TPGLRQ-----LMDEYEKTLSS I IGVQQVPEEETHRYGI ID---PLTSEGRRYQVKNFV 189 PGTMLSVPPAGT AGP WHA IWCAREF IGNDPEAILIPDDVVQSKKSCIGQ-----LVEVYNKTGGNVLAVTEVPREQTGSYGILD---VGKDDGKTVEVKGLV 191 HVTIMQVRQGLAKGLGHAVLCAHPVVGDEPVAVILFDVILDEYESDLSQDNLAEMIRRFDETGHSQIMVEPV-ADVTA-YGVVDCKGVELAPGESVPMVGVV 200 GVT IMNVRQAQP LGLGHS I LCARPVVGDNP F IVVLPD I I IDDATADP LRYNLAAMVARFNETGRSQVLAKRMKGDLSE-YSVIQTKEPLDNEGKVSRIVEF I 196

IIP-PKGTAP SNLAI LGRYVFTPE IF MYLEEQQVGAGGE IQLTDA IQKLNE IQRVF AYDFEGKRYDVGEKLGF ITTTLEFAMQDKELRDQLVPF MEGL LNKEE I TTP-DPKDAP STLSVIGRYVL TADVLKHLAKLEKGAGGEVOLTDAMAKT IGHVPFHGYRYEGKRFDCGSKIASWKPRSP LRWS VRNWLPACVNS

IRCP-KADVAP SNLA I VGRYVLSAD IWP LLAKT P PGAGDE I QLTDA IDML IEKETVEAYHMKGKS HDCGNKLGYMQAFVE YGI RHNT LGTEF KAWLEE EMG IKK EXPDQPQTLDSDLMAVGRYVLSAD IWAELERTEPGAWGR IQLTDAI AE LAKKQSVDAMLMTGD SYDCGKKMGYMQAFVKYGLRNLKEGAKFRKS IEQLLHE

Fig. 3. Alignment of the UDPGPPase amino acid sequences of B. subtilis, A. xylinum, E. coli and S. typhimurium. Gaps (-) were introduced to maximize homologies. Conserved residues are given in bold characters.

\footnotetext{
OrfX MKKLKVMTVFGTRPEAIKMAPLVLELKKYPEIDSYVTVTAQHRQMLDQVLDAFHIKPDFDLNIMKERQTLAEITSNALVRLDELFKDIK 89

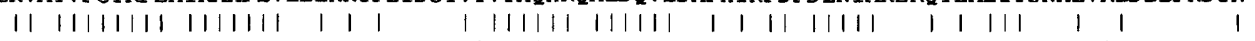
0389 MSAKALAAYSKRIDVKVLTVFGTRPEXIKMAPLVHALAKDPFFEAKVCVTAQHREMLDQVLKLFS IVPDYDLNIMQPGQGLTEITCRILEGLKP ILAEFK 100

OIfX PDIVLVHGDTTTTFAGSLAAFYHQIAVGHVEAGLRTGNKYSPFPEELNRQMTGAIADLHFAPTGQAKDNLLKENKKADSIFVTGNTAIDALNTTVRDGYS 189 0389 PDVVLVHGDTTTTLATSLAAFYQRIPVGHVEAGLRTGDLYSPWPEEANRTLTGHLAMYHFSPTETSRONLIRENVADSRIFITGNTVIDALLWVRDQVMS 200

OrfX HPVLDQVG-----DDKMILLTAHRRENLGEPMENMFKAIRRIVGEFEDVQVVYPVHLNPVVREAAHKHFGDSDRVHL IEPLEVIDFHNFAAKSHF IL 28 1

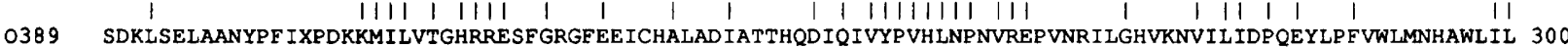

OrfX TDSGGVQEEAPSLGKPVLVLRDTTERPEGVEAGTLKLAGTDEENIYQLAKQLLTDPDEYKKMSQASNPYGDGEASRRIVEELLFHYGYRKEQPDSFTGK 380 ||||| ||||||||||||| |||||||| | ||| | ||| | |l| || || | |||||| | || | |

0389 TDSGGIQEEAPSLGKPVLVMRDTTERPEAVTAGTVRLVGTDKQRIVEEVTRLLKDENEYQAMSRAHNPYGDGQACSRILEALKNNRISL 389
}

Fig. 4. Comparison of the amino acid sequences of the products of orf $X$ and the $E$. coli o389 gene. Identical residues are indicated ( I ). Numbers refer to the C-terminal residue of each fragment. 


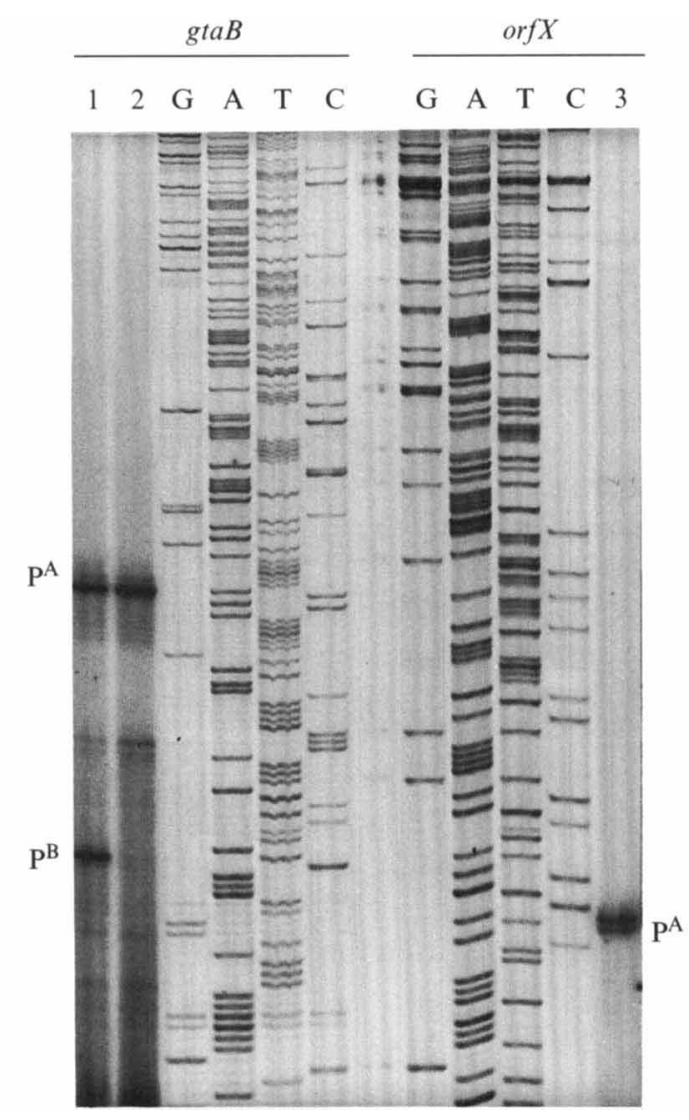

Fig. 5. Identification of transcriptional start points of gtaB and orf $X$ genes by primer extension. The sequencing reactions (lanes $\mathrm{G}, \mathrm{A}, \mathrm{T}, \mathrm{C}$ ) and the corresponding extension reactions (lanes 1 to 3 ) were performed using the same primer. Lanes: 1, RNA from strain IS432 $(\sin \Delta) ; 2$ and 3, RNA from the reference strain 5047.

possibly, orf $X$ expression may provide useful information on the regulation of teichoic acid synthesis. In addition to sequence analysis (see above), we have examined the transcription of these genes by the primer extension method. The ${ }^{32} \mathrm{P} 5^{\prime}$ end-labelled 24-base oligonucleotide primers, complementary to potential gtaB and orf $X$ transcripts between nucleotides +40 and +17 , were annealed to total RNA and extended with the AMV reverse transcriptase. The $5^{\prime}$ end of $\operatorname{orf} X$ mRNA was thus located 39 bases upstream of the putative translation initiation codon (Figs 2 and 5). A reasonable -10 region of an $\sigma^{\mathrm{A}}$-controlled promoter ( 5 out of 6 matches) lies at an appropriate distance from the transcriptional start (Fig. 2). The $-35 \sigma^{\mathrm{A}}$ promoter region (4 out of 6 matches) is separated from the -10 one by a 16-base spacer. The start point of gtaB transcription was localized 80 bases upstream of the potential start codon. It corresponds to a $\mathrm{P}^{\mathrm{A}}$ promoter whose -35 and -10 regions, separated by a perfect 17 -base spacer, exhibit $3 / 6$ and 5/6 matches to $\mathrm{P}^{\mathrm{A}}$ consensus sequences (Fig. 2). Gels of the gtaB transcript reveal a few additional, shorter, primer extension products, characterized by very weak signals (Fig. 5). Absence of any established promoter site, corresponding to all but one of these signals (see below), suggests that they are likely to be artefacts.

Search for a possible role of $g t a B$ and $\operatorname{orf} X$ products in the regulation of the divergon expression was restricted to GtaB since OrfX is essential for cell growth (see below) and, so far, no conditional lethal mutants affected in $\operatorname{orf} X$ have been isolated. Primer extension analysis of mutants L5054 gtaB515, L6200 gtaB 100 and L4598, in which $g t a B$ was inactivated by plasmid insertion, all exhibited start signals identical to that of the wild-type (not presented). Thus, at least in the exponential growth phase, GtaB does not seem to play a role in the regulation of the gtaBorf $X$ divergon. Finally, we examined the role of Sin, a key regulatory protein in B. subtilis differentiation (Gaur et al., 1986), which was shown to be involved in the regulation of the expression of the $\mathrm{N}$ acetylmuramoyl-L-alanine amidase (Fein \& Rogers, 1976; Pooley \& Karamata, 1984; Kuroda \& Sekiguchi, 1993; V. Lazarevic, unpublished results). Primer extension of mutant IS432, $\sin \Delta$ with an inactivated $\sin$ gene, reveals that one of the very weak start points for gtaB transcription (see above), hardly detectable in $\sin ^{+}$ strains, becomes as intense as the one associated with the $\mathrm{P}^{\mathrm{A}}$ promoter (Fig. 5). This start point corresponds to a $\mathrm{P}^{\mathrm{B}}$ promoter previously identified and localized in this region of the $B$. subtilis chromosome (Boylan et al., 1990). Thus, in addition to its numerous functions (Gaur et al., 1986), Sin appears to negatively regulate the transcription from the $\mathrm{P}^{\mathrm{B}}$ promoter of gtaB. Primer extension analysis has not revealed any effect of Sin on orf $X$ transcription (not presented).

\section{Nucleotide sequences of gtaB515 and gtaB 100 mutant alleles}

Phenotypic differences between strains bearing $g t a B$ and gta $B^{g}$ type mutations, revealed by bacteriophage adsorption spectra (Pooley et al., 1987), prompted us to determine the nature of mutations gtaB5 15 and $g t a B^{g} 100$. Firstly, we identified the DNA fragment which can correct both these mutations. p6344A was constructed by insertion of the wild-type ( $\mathrm{gtaB}^{+}$) sequence, encoding residues $1-213$ of the UDPGPPase, into the polylinker region of pMTL500C, a replicative plasmid in $B$. subtilis. Transformation of the $B$. subtilis $\phi 29$-resistant strains, L5054 gtaB515 ( $\left.\phi 29^{\mathrm{r}} \mathrm{PBSZ}^{\mathrm{r}} \mathrm{PSBY}^{\mathrm{r}}\right)$ and L6200 $\mathrm{gtaB}^{\mathrm{g}} 100$ $\left(\phi 29^{r}\right.$ PBSZ $^{s}$ PBSY $^{s}$ ) (Table 3) by p6344A $\left(\mathrm{Cm}^{\mathrm{r}}\right)$ yielded $\mathrm{Cm}^{\mathrm{r}}$ strains, a small proportion of which exhibited the $\mathrm{GtaB}^{+}$phenotype. The latter strains were obtained by the restoration of the $\mathrm{gta}^{+}$allele through recombination. Thus, the two investigated mutations were localized in 
Table 3. Phage resistance pattern of strains examined

\begin{tabular}{lccc}
\hline \hline & \multicolumn{3}{c}{ Bacteriophage } \\
\cline { 2 - 4 } Strain & $\phi 29$ & PBSY & PBSZ \\
\hline L5047 gtaB & $\mathrm{S}$ & $\mathrm{S}$ & $\mathrm{S}$ \\
L5054 gtaB515 & $\mathrm{R}$ & $\mathrm{R}$ & $\mathrm{R}$ \\
L6200 gtaB $^{+} 100$ & $\mathrm{R}$ & $\mathrm{S}$ & $\mathrm{S}$ \\
L4598 gtaB::p6344 & $\mathrm{R}$ & $\mathrm{R}$ & $\mathrm{R}$ \\
\hline
\end{tabular}

$\mathrm{S}$ and $\mathrm{R}$ denote sensitivity and resistance, respectively.

Table 4. Base changes and resulting amino acid replacement in mutants gtaB515 and gtaB 100

\begin{tabular}{clcc}
\hline \hline & \multicolumn{2}{c}{$\begin{array}{c}\text { Codon and } \\
\text { amino acid } \\
\text { change }\end{array}$} & \\
\cline { 2 - 3 } Strain (mutation) & From & To & Position \\
\hline L5054 (gtaB515) & $\begin{array}{l}\text { GAC } \\
\text { (Asp) }\end{array}$ & $\begin{array}{l}\text { GGC } \\
\text { (Gly) }\end{array}$ & 132 \\
L6200 (gtaB 100$)$ & $\begin{array}{l}\text { GCA } \\
\text { (Ala) }\end{array}$ & $\begin{array}{l}\text { GTA } \\
\text { (Val) }\end{array}$ & 117 \\
\hline \hline
\end{tabular}

(a)

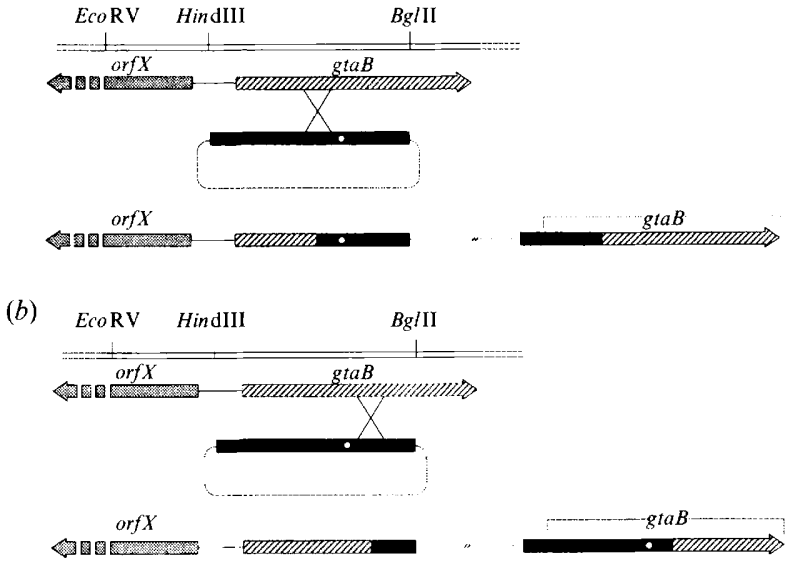

Fig. 6. Integration of p6347 or p6348 into the gtaB locus by recombination upstream $(a)$ and downstream $(b)$ of the gtaB515 and gta $B^{g} 100$ mutation, respectively. The white circle represents the position of the point mutation in the gtaB gene.

the cloned fragment. Chromosomal regions of relevant GtaB-deficient mutants, expected to carry gtaB515 and gtaB 100 , were amplified by PCR. Direct sequencing of thus obtained fragments revealed, in each of the mutants, one single base-pair transition (Table 4). Mutation gtaB515 corresponds to an AT to GC transition at position 1975, resulting in a replacement of an aspartate by a glycine residue at position 132 of the UDPGPPase.
Mutation, $g \operatorname{ta} B^{g} 100$ is due to a CG to TA transition at position 1930, changing alanine into valine at position 117 of the enzyme (Table 4). To confirm that the identified mutations are indeed responsible for the mutant phenotypes, the relevant mutated chromosomal fragments amplified by PCR were introduced into the parent strain. PCR products, digested with HindIII/ BglII, and cloned into pMTL20EC, gave rise to p6347 (gtaB515) and p6348 ( $\mathrm{gtaB}^{\mathrm{g}} 100$ ). Their integration into the $\mathrm{gtaB}$ locus of strain L5047 $\left(\mathrm{gtaB}^{+}\right)$led to a partial duplication of gtaB (Fig. 6). All $\phi 29$-resistant transformants obtained with p6347 (gtaB515) were also PBSY $^{\mathrm{r}}$ and $\mathrm{PBSZ}^{\mathrm{r}}$, while those obtained with $\mathrm{p} 6348$ $\left(\mathrm{gtaB}^{g} 100\right)$ were $\mathrm{PBSY}^{\mathrm{s}}$ and PBSZ ${ }^{\mathrm{s}}$. Phage-resistance patterns were therefore identical to those of the original gtaB mutants, confirming that the two identified point mutations in the $g t a B$ gene were responsible for the specific modifications of phage susceptibility. However, in both crosses, a proportion of $\mathrm{Cm}^{\mathrm{r}}$ recombinants exhibited the wild-type phage sensitivity pattern, i.e. $\phi 29^{\mathrm{s}}$

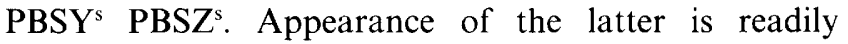
accounted for by recombinational events upstream of the mutation (Fig. $6 a$ ), which leave the wild-type allele in the complete gene copy and place the mutated base pairs in the truncated $g t a B$ copy, conferring wild-type phage sensitivity upon such recombinants.

\section{Insertional mutagenesis of gtaB and orf $X$ genes}

Inactivation of the $g t a B$ gene by insertion of p6344 yielded viable $\mathrm{Cm}^{r}$ recombinants, which were all resistant to bacteriophages $\phi 29$, PBSY and PBSZ. Thus, the resulting, truncated, GtaB protein, which lacks the $79 \mathrm{C}$ terminal amino acid residues, exhibited the phenotype corresponding to mutation gtaB515 (Table 3).

Inactivation of $\operatorname{orf} X$ was attempted by transformation of competent cells of strain L5047 with p6346 or p6350, and selection of $\mathrm{Cm}^{r}$ and erythromycin-resistant $\left(\mathrm{Em}^{\mathrm{r}}\right)$ recombinants. Theoretically, a Campbell-type integration of either of these plasmids should have taken place and led to interruption of $\operatorname{orf} X$ at codon position 334, and thus to a protein devoid of its $46 \mathrm{C}$-terminal amino acids. However, absence of such transformants suggests that the product of $\operatorname{orf} X$ is essential for cell growth. To eliminate the possibility that p6350 is intrinsically impaired in the integration into the chromosome, the $0.6 \mathrm{~kb} \mathrm{HpaI-SacI}$ fragment of $\operatorname{orf} X$ was translocated into gene $a m y E$, generating a partial diploidy of $\operatorname{orf} X$. To that effect, it was cloned in pDG268 (Fig. 7). The resulting p6349, linearized with $S c a$ I, was introduced by transformation into cells of strain L5047. $\mathrm{Cm}^{\mathrm{r}}$ and amylasedeficient transformants, generated by insertion of the $\operatorname{orf} X$ fragment into the amy $E$ gene following a doublecrossover were obtained (Fig. 7). When one chosen $a m y E$ 


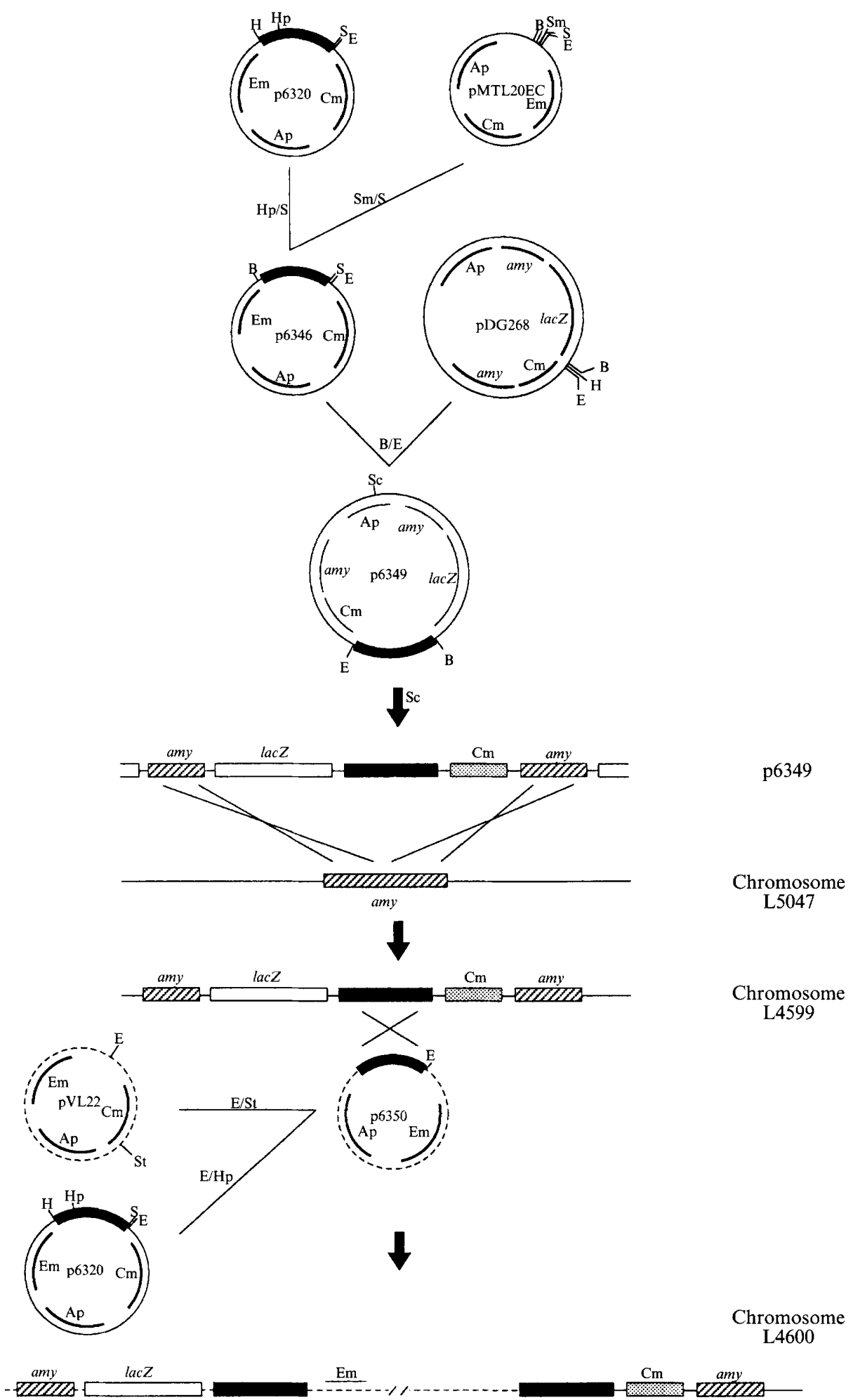

Fig. 7. Strategy for the orf $X$ fragment insertion into the amyE locus and confirmation of the capability of integration for p6350. Restriction sites are as follows: B, BamHI; E, EcoRI; H, HindIII; Hp, HpaI; S, SacI; Sc, ScaI; Sm, SmaI; St, StuI.

recombinant, diploid for part of $\operatorname{orf} X$, strain L4599, was transformed with $\mathrm{p} 6350, \mathrm{Em}^{\mathrm{r}}$ transformants were obtained. Since control PBS1 transduction mapping (not presented) confirmed that $\mathrm{Em}^{\mathrm{r}}$ markers thus introduced were localized in the amyE region, it follows that the product of orf $X$ is indeed essential for cell growth. 


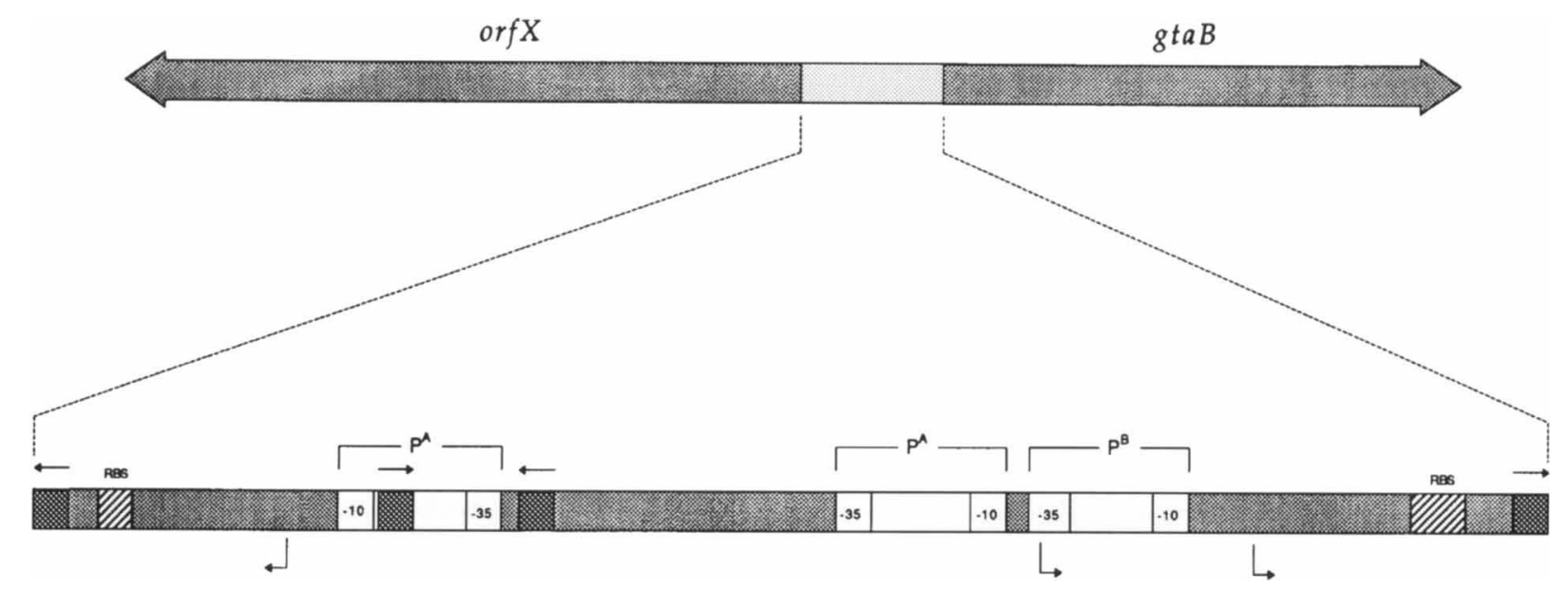

Fig. 8. Schematic drawing of the regulatory region of the gtaBorf $X$ divergon. Black segments refer to the ATGAAA hexamers and the corresponding arrows to their orientation.

\section{Discussion}

Sequence analysis of gtaB, the structural gene of the UDPGPPase in $B$. subtilis 168 , reveals an acidic, apparently soluble, protein with a molecular mass of $33 \mathrm{kDa}$. The enzyme displays a relatively high amino acid sequence homology with analogous enzymes of bacteria A. xylinum, E. coli and S. typhimurium (Fig. 3), but apparently none with the analogous UDPGPPases in the eukaryotes Dictyostelium discoideum (Ragheb \& Dottin, 1987) and potato tuber (Katsube et al., 1990). Inactivation by insertional mutagenesis of the $B$. subtilis gene led to a phenotype characteristic of gtaB-bearing mutants, i.e. resistance to bacteriophages $\phi 29$, PBSY and PBSZ. Strains with mutated $g t a B$ were previously shown to be deficient in poly (Glc-GalNAc 1-P), as well as in glucosylation of the glycerol residue of poly(groP), the main anionic polymer. The divergently transcribed gene $\operatorname{orf} X$, which shares the regulatory region with $g \operatorname{ta} B$, was shown to be essential for cell growth. Absence of conditional mutants did not allow the identification of its biological role. However, a relatively high amino acid sequence homology to the product of the $E$. coli genetic entity 0389 , belonging to a cluster possibly involved in sugar processing, might suggest a role for OrfX in the metabolism of cell surface polymers, such as techoic or lipoteichoic acids, for instance.

From the structural point of view, the divergently transcribed monocistronic operons gtaB and $\operatorname{orf} X$, flanked by two strong $\rho$-independent terminators and sharing a $245 \mathrm{bp}$ regulatory region, form a divergon. However, so far, no evidence of a functional or regulatory interdependence of GtaB and OrfX proteins has been obtained. Sequence and primer extension analyses of the exponentially growing wild-type and $\sin \Delta$-bearing cells show that $\operatorname{orf} X$ is transcribed from a
$\mathrm{P}^{\mathrm{A}}$ promoter, and gtaB from a $\mathrm{P}^{\mathrm{A}}$ and from a Sinrepressed $\mathrm{P}^{\mathrm{B}}$ promoter. The transcription start site corresponding to $\mathrm{P}^{\mathrm{B}}$, hardly detectable in exponentially growing $\sin ^{+}$cells, reveals transcription in strains with an inactivated $\sin$ gene.

Interestingly, the Sin protein, while apparently attenuating the activity of the $\mathrm{P}^{\mathrm{B}}$ promoter of $g t a B$, was shown to enhance that of the $\mathrm{P}^{\mathrm{D}}$ promoter of the lyt $A B C$ operon (Kuroda \& Sekiguchi, 1993). Should such an effect of Sin be valid for transcription from other $\mathrm{P}^{\mathrm{B}}$ and $\mathrm{P}^{\mathrm{D}}$ promoters, it would appear that $\sigma^{\mathrm{B}}$ - and $\sigma^{\mathrm{D}}$-controlled regulons encode antagonizing functions. The regulatory regions of the Sin-repressed $g t a B$ and the Sin-depressed lyt $A B C$ operons each contain two pairs of similar inverted repeats: in $g t a B$, the inverted repeat is an ATGAAA hexamer (Fig. 8), and in lyt $A B C$, it is the ANAATGAAA nonamer (Lazarevic et al., 1992), which includes the former hexamer. A more general confirmation of our observation should help to correlate the effect of Sin with these regulatory elements.

Mutations gtaB515 and $\mathrm{gtaB}^{8} 100$, which confer different phage adsorption spectra, correspond, respectively, to the following amino acid substitutions: glycine for aspartate, which appreciably alters the UDPGPPase hydropathy profile; and valine for alanine. Strains bearing either of these mutations are resistant to phage $\phi 29$ due to absence of its receptor, the glucosylated poly(groP) (Young, 1967). Loss of receptor(s) for defective bacteriophages PBSY and PBSZ, associated with $g t a B$ mutations seems to be correlated with a very severe reduction of the cell wall GalNAc content (Pooley et al., 1987). The presence of small amounts of this compound in $g t a B^{g}$-bearing mutants, possibly due to leakiness of the UDPGPPase, only slightly altered by the replacement of a valine by an alanine residue, might be correlated with their sensitivity to PBSY and PBSZ. 
However, poly(Glc-GalNAc 1-P) is not the specific receptor for these phages: firstly, gga-bearing mutants, characterized by complete absence of this polymer (Estrela et al., 1991), are sensitive to PBSZ (Estrela, 1991), and secondly, a double $g t a B^{g}$ gga mutant remains sensitive to both PBSY and PBSZ (B. Soldo, unpublished results). Therefore, other receptors for PBSY and PBSZ adsorption should be envisaged. For instance, adsorption may require another GalNAc-containing polymer (Duckworth et al., 1972), whose residual synthesis might take place in $g t a B^{g}$-bearing strains, or possibly either the glucosylated poly(groP) or the poly(Glc-GalNAc 1-P) may allow adsorption. Incidentally, the presence of a UDP sugar hydrolase, external to the cytoplasmic membrane in phosphate-starved cultures of $B$. subtilis strain W23 (Mauck \& Glaser, 1970), leaves open the question of a more direct role of this enzyme in the phage-bacterium interaction.

The observation that each of the two characterized mutations of gtaB corresponds to a substitution of an amino acid conserved in the four UDPGPPase prokaryotic genes that have been sequenced so far suggests that the mutated domain encodes the active site of the enzyme. A confirmation of such a correlation, i.e. that missense mutations with a detectable phenotype are due to substitution of conserved amino acids, may not only account for the uneven distribution of thermosensitive mutations (Karamata \& Gross, 1970; D. Karamata, unpublished results) but may, conversely, allow the identification of an active site by sequencing of these mutations.

We are grateful to Dr Catherine Mauël for the generous gift of material and for making available unpublished data. B. Soldo was partly supported by a grant from the Centre for genetic engineering and biotechnology, Sarajevo.

\section{References}

BADDiley, J. (1970). Structure, biosynthesis and function of teichoic acids. Accounts of Chemical Research 3, 98-105.

Boylan, S. A., Kalman, S., Duncan, M. L., Thomas, S. M. \& Price, C. W. (1990). Two genes dependent on Bacillus subtilis $\sigma^{\mathrm{B}}$ are expressed in stationary phase under non-sporulating conditions. In Genetics and Biotechnology of Bacilli, vol. 3, pp. 377-384. Edited by M. M. Zukowski, A. T. Genesan \& J. A. Hoch. San Diego: Academic Press.

Brede, G., FJ ÆR Vik, E. \& VAlla, S. (1991). Nucleotide sequence and expression analysis of the Acetobacter xylinum uridine diphosphoglucose pyrophosphorylase gene. Journal of Bacteriology 173, $7042-7045$.

Chambers, S. P., Prior, S. E., Barstow, D. A. \& Minton, N. P. (1988). The pMTL nic-cloning vectors. I. Improved pUC polylinker region to facilitate the use of sonicated DNA for nucleotide sequencing. Gene 68, 139-149.

Chung, C. T. \& Miller, R. H. (1988). A rapid and convenient method for the preparation and storage of competent bacterial cells. Nucleic Acids Research 16, 3580.

Daniels, D., Plunkett, G., III, Burland, V. \& Blattner, F. R. (1992). Analysis of the Escherichia coli genome: DNA sequence of the region from 84.5 to 86.5 minutes. Science 257, 771-778.
Del Sal, G., Manfioletti, G. \& Schneider, C. (1988). A one-tube plasmid DNA mini-preparation suitable for sequencing. Nucleic Acids Research 16, 9878.

Devereux, J., Haeberli, P. \& Smithies, O. (1984). A comprehensive set of sequence analysis programs for the VAX. Nucleic Acids Research 12, 387-395.

Dubnau, D., Goldthwaite, C., Smith, J. \& Marmur, J. (1967). Genetic mapping in Bacillus subtilis. Journal of Molecular Biology 27, $163-185$.

Duckworth, M., Archibald, A. R. \& Baddiley, J. (1972). The location of $\mathrm{N}$-acetylgalactosamine in the walls of Bacillus subtilis 168. Biochemical Journal 130, 691-696.

Estrela, A.-I. (1991). Components da parede celular envolvidos na adsorção de fagos temperados de Bacillus subtilis. PhD thesis, University of Lisboa, Portugal.

Estrela, A.-I., Pooley, H. M., De Lencastre, H. \& Karamata, D. (1991). Genetic and biochemical characterization of Bacillus subtilis 168 mutants specifically blocked in the synthesis of the techoic acid poly(3-O- $\beta$-D-glucopyranosyl- $N$-acetylgalactosamine 1-phosphate): gne $A$, a new locus, is associated with UDP- $N$-acetylglucosamine 4epimerase activity. Journal of General Microbiology 137, 943-950.

FEIN, J. E. \& RoGERS, H. J. (1976). Autolytic enzyme-deficient mutants in Bacillus subtilis 168. Journal of Bacteriology 127, 1427-1442.

Ferrari, F. A., Nguyen, A., Lang, D. \& Hoch, J. A. (1983). Construction and properties of an integrable plasmid for Bacillus subtilis. Journal of Bacteriology 154, 1513-1515.

Gaur, N. K., Dubnau, E. \& Smith, I. (1986). Characterisation of a cloned Bacillus subtilis gene that inhibits sporulation in multiple copies. Journal of Bacteriology 168, 860-869.

Gilman, M. Z. \& Chamberlin, M. J. (1983). Developmental and genetic regulation of Bacillus subtilis genes transcribed by $\sigma^{28}$-RNA polymerase. Cell 35, 285-293.

Hassid, W. Z. (1969). Biosynthesis of oligosaccharides and polysaccharides in plants. Science 165, 137-144.

Heery, D. M., Gannon, F. \& Powell, R. (1990). A simple method for subcloning DNA fragments from gel slices. Trends in Genetics $6,173$.

IONesco, H., Ryter, A. \& Schaeffer, P. (1964). Sur un bactériophage hébergé par la souche Marburg de Bacillus subtilis. Annales de I'Institut Pasteur 107, 764-776.

Jiang, X.-M., Neal, B., Santiago, F., Lee, S. J., Romana, L. K. \& REEVES, P. R. (1991). Structure and sequence of the $r f b$ (O antigen) gene cluster of Salmonella serovar typhimurium (strain LT2). Molecular Microbiology 5, 695-713.

Jones, K. A., Yamamoto, K. R. \& Tuian, R. (1985). Two distinct transcription factors bind to the HSV thymidine kinase promoter in vitro. Cell 42, 559-572.

Karamata, D. \& Gross, J. D. (1970). Isolation and genetic analysis of temperature-sensitive mutants of $B$, subtilis defective in DNA synthesis. Molecular and General Genetics 108, 277-287.

Karamata, D., Pooley, H. M. \& Monod, M. (1987). Expression of heterologous genes for wall teichoic acid in Bacillus subtilis 168. Molecular and General Genetics 207, 73-81.

Katsube, T., Kazuta, Y., Mori, H., Nakano, K., Tanizawa, K. \& FUKUI, T. (1990). UDP-glucose pyrophosphorylase from potato tuber: cDNA cloning and sequencing. Journal of Biochemistry 108 321-326.

KuRODA, A. \& SeKIguchi, J. (1993). High-level transcription of the major Bacillus subtilis autolysin operon depends on expression of the sigma D gene and is affected by a $\sin (f a D)$ mutation. Journal of Bacteriology 175, 795-801.

Lazarevic, V., Margot, P., Soldo, B. \& Karamata, D. (1992). Sequencing and analysis of the Bacillus subtilis lyt $R A B C$ divergon: a regulatory unit encompassing the structural genes of the $N$ acetylmuramoyl-L-alanine amidase and its modifier. Journal of General Microbiology 138, 1949-1961.

MARMUR, J. (1961). A procedure for the isolation of deoxyribonucleic acid from micro-organisms. Journal of Molecular Biology 3, 208-218.

MaUCK, J. \& Glaser, L. (1970). Periplasmic nucleoside diphosphate sugar hydrolase from Bacillus subtilis. Biochemistry 9, 1140-1147.

MaUËL, C. \& Karamata, D. (1984). Prophage induction in thermosensitive DNA mutants of Bacillus subtilis. Molecular and General Genetics 194, 451-456. 
Mauël, C., Young, M., Margot, P. \& Karamata, D. (1989). The essential nature of teichoic acids in Bacillus subtilis as revealed by insertional mutagenesis. Molecular and General Genetics 215, 388-394.

Miller, K. J., Kennedy, E. P. \& Reinhold, V. N. (1986). Osmotic adaptation by gram-negative bacteria: possible role for periplasmic oligosaccharides. Science 231, 48-51.

Pooley, H. M. \& Karamata, D. (1984). Genetic analysis of autolysindeficient and flagellaless mutants of Bacillus subtilis. Journal of Bacteriology 160, 1123-1129.

Pooley, H. M., Paschoud, D. \& Karamata, D. (1987). The gtaB marker in Bacillus subtilis 168 is associated with a deficiency in UDPglucose pyrophosphorylase. Journal of General Microbiology 133, 3481-3493.

RAGHEB, J. A. \& Dotrin, R. P. (1987). Structure and sequence of a UDP glucose pyrophosphorylase gene of Dictyostelium discoideum. Nucleic Acids Research 15, 3891-3906.

Sambrook, J., Fritsch, E. F. \& Maniatis, T. (1989). Molecular Cloning : a Laboratory Manual, 2nd edn. Cold Spring Harbor, New York: Cold Spring Harbor Laboratory.

Schulman, H. \& KenNedy, E. P. (1977). Identification of UDPglucose as an intermediate in the biosynthesis of membrane-derived oligosaccharides of Escherichia coli. Journal of Biological Chemistry 252, 6299-6303.
Shedlovsky, A. \& Brenner, S. (1963). A chemical basis for the hostinduced modification of T-even bacteriophages. Proceedings of the National Academy of Sciences of the United States of America 50, 300-305.

Shibaev, V. M., Duckworth, M., Archibald, A. R. \& Baddiley, J. (1973). The structure of a polymer containing galactosamine from walls of Bacillus subtilis 168. Biochemical Journal 135, 383-384.

Sundararajan, T. A., Rapin, A. M. C. \& Kalckar, H. M. (1962). Biochemical observation on $E$. coli mutants defective in uridine diphosphoglucose. Proceedings of the National Academy of Sciences of the United States of America 48, 2187-2192.

Tinoco, I., Borer, P. N., Dengler, B., Levine, M. D., Uhlenbeck. O. C., Crothers, D. M. \& Gralla, J. (1973). Improved estimation of secondary structure in ribonucleic acids. Nature New Biology 246, $40-41$.

White, A., Handler, P., Smith, E. L. (1973). Principles of Biochemistry, 5th edn. Kogakusha: McGraw-Hill.

YouNG, F. E. (1967). Requirement of glucosylated teichoic acid for adsorption of phage in Bacillus subtilis 168. Proceedings of the National Academy of Sciences of the United States of America 58 , 2377-2384

Young, F. E., Smith, C. \& Reilly, B. E. (1969). Chromosomal location of genes regulating resistance to bacteriophage in Bacillus subtilis. Journal of Bacteriology 98, 1087-1097. 